\title{
Pembelajaran Menulis Teks Editorial Melalui Penerapan Strategi Pemodelan Pada Siswa Kelas XII SMA Negeri 1 Tahuna
}

\author{
Non Evelin Karimang, Donal M. Ratu, Nontje J. Pangemanan \\ Jurusan Pendidikan Bahasa dan Sastra Indonesia, Fakultas Bahasa dan Seni, Universitas Negeri \\ Manado \\ nonevelin.karimang@gmail.com,donaldratu@unima.ac.id,nontjepangemanany@gmail.com
}

\begin{abstract}
Abstrak: Tujuan penelitian ini adalah: 1) menggambarkan penerapan strategi pemodelan dalam pembelajaran menulis teks editorial pada siswa kelas X SMA Negeri 1 Tahuna dan 2) menggambarkan kemampuan menulis teks editorial siswa kelas XII SMA Negeri 1 Tahuna melalui penerapan strategi pemodelan.Metode yang digunakan dalam penelitian ini adalah metode deskriptif analitik. Sumber data penelitian adalah siswa kelas XII IPSa, yang berjumlah 23 orang. Teknik penelitian menggunakan pengamatan dan tes. Cara analisis data memadukan cara analisis deskriptif dan kuantitatif . Hasil penelitian menunjukkan: 1) penggunaan strategi pemodelan dalam menulis teks editorial memberikan kesempatan yang begitu besar kepada siswa terlibat secara aktif dalam pembelajaran menulis. Penggunaan strategi pemodelan yang digunakan dalam pembelajaran menulis teks editorial pada siswa kelas XIIA SMA Negeri 1 Tahuna memfokuskan kegiatan siswa pada menelaah dan menulis teks editorial. 2) Kemampuan siswa menulis teks editorial dengan strategi pemodelan adalah $81.71 \%$ atau berada pada kategori mampu. Nilai rata-rata siswa secara klasikal yang dicapai siswa melampaui Kriteria Ketuntasan Minimal (KKM) yang ditentukan guru bahasa Indonesia di kelas XII SMA Negeri 1 Tahuna, yakni $78 \%$, maka nilai rata-rata yang dicapai oleh siswa ini secara klasikal melampaui ketuntasan minimal.
\end{abstract}

Kata Kunci: Pembelajaran, Menulis, Strategi Pemodelan

\section{PENDAHULUAN}

Bahasa Indonesia merupakan mata pelajaran wajib dari jenjang pendidikan dasar sampai pendidikan menengah atas. Sebagai mata pelajaran wajib, mata pelajaran bahasa Indonesia di sekolah berperan penting mengasah keterampilan berbahasa, mengasah kecerdasan berpikir kritis, dan mengasah kepekaan emosional siswa. Karena itu, tidak bisa disangkal, keberadaan bahasa Indonesia di sekolah merupakan sarana vital untuk pembelajaran semua mata pelajaran. Bahasa Indonesia merupakan media komunikasi utama melaksanakan pembelajaran pada setiap mata pelajaran.

Bahasa Indonesia sebagai mata pelajaran dijabarkan dalam empat keterampilan berbahasa, yakni menyimak, berbicara, membaca, dan menulis. Namun demikian, dalam praktiknya, pembelajaran empat keterampilan ini menjadi satu kesatuan yang tidak bisa dipisahkan. Karena itu, dalam kurikulum 2013, pembelajaran empat keterampilan berbahasa ini terintegrasi dengan memanfaatkan teks sebagai media utamanya. Mahsun (2014:6) teks menjadi basis pembelajaran bahasa Indonesia, baik lisan maupun tulisan, sehingga dalam kurikulum 2013 empat keteramplann berbahasa ini tidak terpisah atau berdiri sendiri, berbeda dengan kurikulum 2014 mengelompokkan kompetensi dasar pembelajaran berdasarkan empat keterampilan berbahasa. Pembelajaran bahasa Indonesia dalam kurikulum 2013 menekan bahwa mempelajari sebuah teks melewati lima kegiatan, yakni memahami/ menelaah, menanggapi, mengonstruski/memproduksi, dan mengonversi teks.

Dari tahapan-tahapan mempelajari sebuah teks terdapat kegiatan ketiga, yaitu mengonstruksi atau memproduksi sebuah teks. Secara tersirat bahwa mengonstruksi atau memproduksi teks mewajibkan siswa menghasilkan sebuah teks tulis, sesuai jenis teks yang dipelajari. Artinya, siswa dapat menyusn atau menulis sebuah teks sesuai kompetensi dasar yang dipelajari. Menulis teks merupakan salah satu cara melatih siswa menuangkan pikiran dan perasaan lewat kata-kata dan kalimat-kalimat. 
Penekanannya adalah siswa dilatih mampu mengekspresikan berbagai pikiran, gagasan, pendapat, dan perasaan dalam berbagai ragam tulisan (Depdiknas, 2004:4).

Agar siswa dapat menyusun atau menulis sebuah teks, maka guru memiliki peran yang sangat penting. Peran guru adalah memberikan bimbingan dan latihan secara terus menerus kepada siswa menulis beragam teks. Keterampilan siswa menghasilkan teks tulis tidak akan terbentuk begitu saja, tetapi melalui pembelajaran yang terarah, yaitu langsung melibatkan siswa menulis sebuah teks. Sebab itu, melaksanakan pembelajaran menulis tidak boleh dilaksanakan sesukanya oleh guru, apalagi sekedar memenuhi tuntutan kurikulum. Fakta yang terjadi dalam pembelajaran menulis sebuah teks adalah munculnya anggapan siswa bahwa menulis mereka lakukan adalah untuk memenuhi tugas yang diberikan guru, bukan atas keinginan mereka.

Kurikulum 2013 yang menggunakan pendekatan teks menuntut siswa mempelajari beragam teks. Siswa dituntut menghasilkan beragam teks berdasarkan genrenya. Misalnya, untuk siswa kelas X SMA, pada semester genap siswa wajib mempelajari salah satu jenis teks, yaitu teks editorial. Kompetensi Dasarnya adalah "Memproduksi teks editorial" (Setiarini dan Artini 2018:68). Jika dilihat dari jenisnya, teks editorial termasuk kategori teks berita. Teks editorial menurut Sugondo, dkk. ( 2005:154) yakni "artikel dalam surat kabar atau majalah yang mengungkapkan pendirian editor atau pimpinan surat kabar atau majalah mengenai permasalahan yang aktual". Jadi teks editorial ditulis sendiri oleh redaktur yang mengelola koran atau majalah yang isinya berupa tanggapan dan sikap kritis redaktur terhadap permasalahan yang sedang hangat.

Sebagai salah satu teks yang wajib dipelajari oleh siswa, semestinya pembelajaran teks editorial yang memiliki karakteristik tersendiri perlu diajarkan secara baik oleh guru. Namun demikian, kenyataanya sampai sekarang pembelajaran menulis teks editorial belum sepenuhnya dilakukan dengan baik oleh guru. Hal ini berdampak kurang baik pada kemampuan siswa menulis teks editorial belum seperti apa yang diharapkan. Permasalahan ini dialami oleh siswa kelas XII SMA Negeri 1 Tahuna. Data awal ini diperoleh melalui wawancara dengan guru mata pelajaran bahasa Indonesia kelas XII SMA Negeri 1 Tahuna.

Berdasarkan data awal diperoleh informasi bahwa permasalahan tersebut disebabkan karena cara guru dalam mengajar kurang bervariasi, kurang merangsang, dan monoton. Guru kesulitan menemukan strategi pembelajaran yang sesuai. Pembelajaran menulis yang dilakukan oleh guru masih berpola pada strategi lama, di mana guru langsung menjelaskan teks editorial dan menyuruh siswa menulis. Guru juga tidak memberikan contoh teks editorial kepada siswa sebagai acuan untuk menulis dan kurang memberikan bimbingan saat siswa menulis teks editorial.

Pembelajaran menulis teks editorial yang dilakukan guru polanya perlu dioptimalkan. Salah satu caranya adalah mengubah strategi pembelajaran yang menekankan pada siswa aktif. Guru harus menempatkan siswa sebagai subjek yang aktif dan kreatif, sehingga guru perlu bertindak sebagai fasilitator dan pembimbing yang baik. Selain itu, guru perlu memperkenalkan contoh-contoh teks editorial dari beberapa surat kabar sebagai model yang dapat ditiru oleh siswa, sebab keberhasilan pembelajaran menulis di sekolah salah satu ditentukan oleh faktor guru. Guru diharapkan mampu memilih strategi pembelajaran yang sesuai dan memadukan dengan strategi pembelajaran yang lain agar pembelajaran lebih bervariasi.

Salah satu straegi pembelajaran menulis teks editorial yang sesuai adalah strategi pemodelan. Strategi peodelan adalah strategi di mana siswa diberikan beragam contoh teks (Devita Sari, G. 2015:7). Misalnya comtoh teks editorial dari berbagai surat kabar, sehingga memberikan pemahaman secara mendalam tentang karakteristik isi dan kebahsaan teks editorial. Dengan demikian, siswa dapat memilih salah satu contoh dari berbagai teks editorial yang akan dijadikan sebagai model atau acuan penulisan. Berdasarkan penjelasan tersebut, strategi ini memiliki kecocokan digunakan dalam pembelajaran menulis teks editorial. Hal ini didasari oleh pandangan bahwa kemampuan menulis siswa dapat meningkat bila guru berupaya merancang strategi pembelajaran yang lebih efektif dan inovatif. Strategi pemodelan diharapkan menjadi satu solusi mengatasi kesulitan siswa menulis teks editorial, sehingga harapanya kualitas tulisan yang dihasilkan oleh siswa menjadi lebih baik.

Penelitian ini bertujuan: (1) menggambarkan penerapan strategi pemodelan dalam pembelajaran menulis teks editorial pada siswa kelas X SMA Negeri 1 Tahuna dan (2) menggambarkan kemampuan menulis teks editorial siswa kelas XII SMA Negeri 1 Tahuna melalui penerapan strategi pemodelan. 


\section{METODE}

Penelitian ini menggunakan metode deskriptif analitik. Sukmadinata (2009:72) mengemukakan penelitian deskriptif analitik mengkaji bentuk, aktivitas, karakteristik, perubahan, hubungan, kesamaan dan perbedaannya dengan fenomena lain. Metode ini sesuai untuk meneliti objek dalam konteks pembelajaran, yakni pembelajaran menulis teks editorial dengan strategi pemodelan pada siswa kelas XII SMA Negeri 1 Tahuna.

Penelitian dilaksanakan di SMA Ngeri 1 Tahuna, khususnya siswa kelas XII IPSa semester genap, Tahun Pelajaran 2018/2019. Waktu penelitian dilaksanakan antara bulan Januari sampai dengan April 2019. Yang menjadi sumber data dalam penelitian ini adalah siswa kelas XII IPSa SMA Negeri 1 Tahuna yang berjumlah 23 orang siswa. Penelitian ini menggunakan teknik observasi dan tes. Observasi digunakan untuk mengumpulkan data proses pembelajaran menulis teks editorial dengan model strategi pemodelan yang berlangsung di kelas. Jenis tes yang digunakan dalam penelitian untuk mengetahui kemampuan siswa menulis teks editorial adalah tes tindakan, yaitu siswa diminta menulis teks editorial secara utuh. Aanalisi data yang terkumpul digunakan dengan dua cara, yakni analisis kualitatif dan analisis kuantitatif. Analisis kualitatif digunakan untuk menganalisis proses pelaksanaan pembelajaran dan analisis data secara kuatitatif digunakan untuk mengetahui kemampuan menulis teks editorial siswa.

\section{HASIL DAN PEMBAHASAN}

\section{Pembelajaran Menulis Teks Editorial dengan Strategi Pemodelan}

\section{Pendahuluan}

Pembelajaran menulis teks editorial yang telah dilaksanakan dalam penelitian dengan strategi pemodelan mengikuti empat langkah inti, yaitu: 1) membagikan teks model, 2) membaca teks model, 3) menelaah isi, strukutur, dan aspek kebahasan teks model, 4) berlatih menulis. Namun dalam pelaksanaan kegiatan, proses pembelajaran yang dilakukan guru terdiri dari tiga tahapan, yaki pendahuluan, inti, dan penutup. Pada tahap intilah, strategi pemodelan dilaksanakan. Proses pembelajaran yang telah dilaksanakan guru digamabrkan berikut.

Pembelajaran yang dilaksankan pada tahap pendahuluan meliputi: guru membuka pelajaran, menyajikan materi dan tujuan pembelajaran, melakukan apersepsi, membagi kelompok, dan menjelaskan kegiatan belajar siswa. Guru menyapa dan memotivasi siswa untuk menarik perhatian mereka mengikuti pelajaran. Guru dapat membuka pelajaran dengan rileks mempersiapkan siswa belajar. Setelah membuka pelajaran dan memotivasi siswa, guru menyampaikan materi pembelajaran yang dipelajari dan tujuan pembelajaran yang hendak dicapai. Untuk memudahkan siswa memahami materi dan tujuan pembelajaran, guru menuliskannya di papan tulis. Saat guru menyampaikan materi dan tujuan pembelajaran, siswa tampak serius memperhatikan. Guru secara langsung menjelaskan KD dan tujuan pembelajaran yang hendak dicapai. Kompetensi dasar pembelajaran adalah "Mengonstruksi teks editorial". Tujuan pembelajaran adalah peserta didik dapat mengonstruksi atau menyusun teks editorial dengan memperhatikan struktur dan aspek kebahasaan yang sesuai.

Setelah menyampaikan KD dan tujuan pembelajaran, guru melakukan apersepsi. Guru berusaha menghubungkan materi pelajaran yang dipelajari dengan pengetahuan dan pengalaman siswa berkaitan dengan teks editorial. Guru mengajukan pertanyaan kepada siswa untuk mengetahui pengetahuan mereka tentang teks editorial.

Setelah menjelaskan materi pelajaran, guru kembali melakukan tanya jawab dengan siswa. Hal ini dilakukan guru untuk mengecek apakah siswa telah memahami materi pelajaran yang baru dijelaskan. Dari tanya jawab yang dilakukan tampak siswa sudah memahami pengertian, isi, strukutur, dan aspek kebahasaan teks editorial.

\section{Kegiatan Inti}

Pada kegiatan inti, guru mengarahkan siswa melaksanakan empat kegiatan utama strategi pemodelan. Guru mengingatkan kembali kepada siswa bahwa pelaksanaan kegiatan merupakan pengembangan dari materi yang telah dijelaskan. Kegiatan pada tahap ini digambarkan berikut. 


\section{Membagikan Teks Model}

Guru membagikan dua teks editorial yang dijadikan model kepada semua siswa. Kemudian guru menjelaskan kegiatan yang akan dilakukan terhadap dua teks model yang telah dibagikan. Dua teks model berjudul "Upaya Meningkatkan Mutu Pendidikan" dan "Perlukah Ujian On-line Dilakukan?"

\section{Membaca Teks Model}

Pada tahap inti kedua strategi pemodelan ini, guru mengarahkan semua siswa membaca dua contoh teks editorial yang telah dibagikan. Guru meminta siswa membaca kedua contoh teks editorial tersebut dalam hati selama 15 menit. Saat kegiatan ini berlangsung tampak semua siswa serius membaca dalam hati dua contoh teks editorial yang dibagikan guru. Untuk memastikan semua siswa membaca, guru berkeliling di dalam ruangan kelas.

\section{Menelaah Isi, Struktur, dan Aspek Kebahasaan Teks Model}

Setelah siswa selesai membaca dalam hati dua contoh teks editorial yang dibagikan, guru mengarahkan siswa melaksanakan kegiatan inti ketiga, yakni menelaah isi, struktur, dan aspek kebahasaan teks editorial yang dijadikan model, baik teks editorial pertama yang berjudul "Upaya Meningkatkan Mutu Pendidikan" dan teks editorial kedua yang berjudul "Perlukah Ujian On-Line Dilakukan?".

Untuk menelaah kedua teks editorial yang dijadikan model ini, guru mengarahkan siswa untuk belajar kelompok. Guru membagi siswa menjadi enam kelompok, terdiri dari 4-5 orang setiap kelompok. Guru memberi perintah kepada siswa mendiskusikan isi, strukur, dan aspek kebahasaan kedua teks editorial. Pada saat mengerjakan tugas dalam kelompok, terjadi diskusi antar siswa dan diskusi berlangsung dengan seru. Ternyata isi teks editorial sangat menarik bagi mereka. Karena itu, untuk mengarahkan diskusi kelompok, guru berpindah dari satu kelompok ke kelompok lain mengarahkan diskusi yang berlangsung.

Kegiatan inti ketiga ini dilanjutkan dengan presentasi hasil diskusi kelompok. Dari hasil presentasi semua kelompok tergambar bahwa siswa dapat menelaah isi, struktur, dan aspek kebahasaan dua contoh teks editorial yang telah dibagikan. Tergambar pula bahwa kedua teks ini sungguh menarik bagi siswa, sehingga saat presentasi kelompok berlangsung terjadi juga perdebatan yang seru.

\section{Berlatih Menulis Teks Editorial}

Pada tahap inti ke empat strategi pemodelan, siswa berlatih menulis teks editorialmengikuti pola dua teks editorial yang telah dipelajari sebagai acuan. Sebelum siswa menulis, guru memberikan arahan kepada siswa tentang menulis teks editorial. Siswa akan menulis memilih topik yang dipilih oleh guru. Topik yang dipilih oleh guru adalah "Bijak Menggunakan Media Sosial".

Setelah guru memberi arahan, mulailah siswa secara sendiri-sendiri menulis teks editorial sesuai topik atau permasalahan yang diberikan guru yaitu "Bijak Menggunakan Media Sosial. Terlihat siswa ternyata lebih dulu menentukan judul teks sesuai topik. Kadang mereka bertanya kepada guru apakah judul yang mereka tentukan sudah sesuai. Tampak suasana menjadi tenang, karena siswa begitu serius menulis teks editorial. Setelah semua siswa selesai menulis, guru mengumpul pekerjaan mereka untuk diperiksa. Kemudian menutup pembelajaran.

\section{Kemampuan Siswa Menulis Teks Editorial dengan Strategi Pemodelan}

Hasil tulisan siswa berupa teks editorial yang telah diperiksa guru menunjukkan hasil yang positif. Data tentang kemampuan siswa menulis teks editorial ditampilkan pada tabel berikut. 
Tabel 1. Kemampuan Siswa Menulis Teks Editorial

\begin{tabular}{|c|c|c|c|c|c|c|c|}
\hline \multirow[t]{2}{*}{ No } & \multirow[t]{2}{*}{ Kode Siswa } & \multicolumn{4}{|c|}{ Aspek Penilaian/ Skor } & \multirow{2}{*}{$\begin{array}{c}\text { Jumlah } \\
\text { Skor }\end{array}$} & \multirow[t]{2}{*}{ Nilai } \\
\hline & & I & II & III & IV & & \\
\hline 1. & S01 & 18 & 17 & 17 & 12 & 64 & 85 \\
\hline 2. & S02 & 19 & 18 & 18 & 13 & 68 & 90 \\
\hline 3. & S03 & 18 & 17 & 16 & 13 & 64 & 85 \\
\hline 4. & S04 & 17 & 17 & 17 & 12 & 63 & 84 \\
\hline 5. & S05 & 19 & 18 & 18 & 14 & 69 & 92 \\
\hline 6. & S06 & 17 & 16 & 16 & 12 & 61 & 81 \\
\hline 7. & S07 & 17 & 16 & 16 & 13 & 62 & 82 \\
\hline 8. & S08 & 16 & 15 & 15 & 13 & 59 & 78 \\
\hline 9. & S09 & 18 & 17 & 17 & 12 & 64 & 85 \\
\hline 10. & S10 & 19 & 18 & 18 & 13 & 68 & 90 \\
\hline 11. & S11 & 18 & 17 & 16 & 13 & 64 & 85 \\
\hline 12. & S12 & 17 & 17 & 17 & 12 & 63 & 84 \\
\hline 13. & S13 & 19 & 18 & 18 & 14 & 69 & 92 \\
\hline 14. & S14 & 17 & 16 & 16 & 12 & 61 & 81 \\
\hline 15. & S15 & 17 & 16 & 16 & 13 & 62 & 82 \\
\hline 16. & S16 & 16 & 15 & 15 & 13 & 59 & 78 \\
\hline 17. & S17 & 18 & 17 & 16 & 13 & 64 & 18 \\
\hline 18. & S18 & 17 & 17 & 17 & 12 & 63 & 84 \\
\hline 19. & S19 & 19 & 18 & 18 & 14 & 69 & 92 \\
\hline 20. & S20 & 17 & 16 & 16 & 12 & 61 & 81 \\
\hline 21. & S21 & 17 & 16 & 16 & 13 & 62 & 82 \\
\hline 22. & S22 & 16 & 15 & 15 & 13 & 59 & 78 \\
\hline 23 & S23 & 16 & 15 & 15 & 13 & 59 & 78 \\
\hline
\end{tabular}

Data pada di atas menunjukkan nilai tertinggi siswa adalah 92 dan nilai terendah adalah 78. Data pada tabel itu juga memperlihatkan perbedaan nilai siswa pada empat aspek penilaian yang dijadikan indicator penilaian. Selanjutnya, dihitung nilai rata-rata siswa secara klasikal. Berdasarkan data pada tabel 1 maka nilai rata-rata secara klasikal kemampuan siswa menulis teks editorial dengan strategi belajar pemodelan, yakni:

$$
\begin{gathered}
\mathrm{X}=\frac{n}{N} \\
\mathrm{X}=\frac{1.867}{23} \\
\mathrm{X}=\mathbf{8 1 . 1 7}
\end{gathered}
$$

Setelah dihitung dengan rumus hitung rata-rata maka dapat diketahui kemampuan siswa menulis teks editorial dengan strategi pemodelan adalah $\mathbf{8 1 . 7 1}$ atau berada pada kategori mampu. Nilai ratarata siswa secara klasikal yang dicapai siswa melampaui Kriteria Ketuntasan Minimal (KKM) yang ditentukan guru bahasa Indonesia di kelas XII SMA Negeri 1 Tahuna, yakni 78, maka nilai rata-rata yang dicapai oleh siswa ini secara klasikal melampaui ketuntasan minimal.

Jadi, dari hasil analisis yang dilakukan diperoleh hasil penelitian bahwa kemampuan siswa kelas XII SMA Negeri 1 Tahuna menulis teks editorial, baik secara individu, maupun klasikal memenuhi ketuntasan minimal, di mana tidak ada siswa yang mengikuti remedial. Dengan demikian, penerapan strategi pemodelan dapat memampukan siswa kelas XII SMA Negeri Tahuna menulis teks editorial.

Berdasarkan hasil penelitian yang telah dilakukan diperoleh temuan bahwa penggunaan strategi pemodelan merupakan satu alternatif untuk mengatasi permasalahan yang dialami siswa dalam pembelajaran menulis teks editorial. Penggunaan strategi pemodelan dalam menulis teks editorial terdiri dari empat tahapan inti ternyata memberikan kesempatan yang begitu besar kepada siswa terlibat secara aktif dalam pembelajaran menulis. Posisi guru dalam pembelajaran menulis teks editorial tidak menguasai proses pembelajaran, tetapi lebih menitikberatkan kepada siswa. Hasil ini sejalan dengan 
pendapat Arends, (2008:12) pembelajaran kreatif mengharuskan bahwa selama proses belajar berlangsung harus melibatkan siswa aktif di dalam setiap tahapan kegiatan yang dirancang guru.

Hasil penelitian menunjukkan juga bahwa penggunaan strategi pemodelan yang digunakan dalam pembelajaran menulis teks editorial pada siswa kelas XIIA SMA Negeri 1 Tahuna memfokuskan kegiatan pada menelaah terlebih dahulu teks model, Siswa diberi dua teks model yang mereka dapat jadikan sebagai acuan sehingga mereka dapat menulis dengan baik. Pengalaman relevan yang mereka miliki berkaitan dengan materi pembelajaran sangat membantu mereka menguasai materi yang dipelajari. Dengan menelaah terlebih dahulu teks editorial yang dijadikan model sebagai acuan tarnayata memberikan pengetahuan dan pemahaman kepada siswa menulis teks editorial. Hal ini ternyata sangat membantu siswa, karena dalam strategi pemodelan memiliki ciri, seperti dikemukakan oleh Devitha Sari (2015: 6) yakni: 1) terjadi proses peniruan, 2) siswa mempelajari apa yang ingin diikuti atau dipelajari, 3) siswa melakukan seperti yang dimodelkan di bawah arahan atau bimbingan guru, dan 4) menuntut siswa aktif dan mandiri.

Berlangsungnya proses pembelajaran menulis teks editorial secara baik memberikan dampak langsung terhadap hasil belajar siswa. Temuan ini sejalan dengan hasil penelitian Devitha Sari (2015: 6) bahwa pembelajaran dengan strategi pemodelan dapat membantu siswa mengembangkan sebuah tulisan, karena ada contoh teks model yang diacu. Dari hasil pengolahan data yang dilakukan menunjukkan bahwa nilai rata-rata secara klasikal kemampuan siswa setelah dihitung dengan rumus hitung rata-rata maka dapat diketahui kemampuan siswa menulis teks editorial dengan strategi pemodelan adalah $\mathbf{8 1 . 7 1}$ atau berada pada kategori mampu. Nilai rata-rata siswa secara klasikal yang dicapai siswa melampaui Kriteria Ketuntasan Minimal (KKM) yang ditentukan guru bahasa Indonesia di kelas XII SMA Negeri 1 Tahuna, yakni 76. Hasil penelitian ini menegaskan bahwa strategi pemodelan memiliki keunggulan jika digunsksn dengsn benar.

Jadi, dari hasil analisis yang dilakukan diperoleh hasil penelitian bahwa kemampuan siswa kelas XII SMA Negeri 1 Tahuna menulis teks editorial dengan strategi pemodelan, baik secara individu, maupun klasikal memenuhi ketuntasan minimal, di mana tidak ada siswa yang mengikuti remedial. Dengan demikian, penerapan strategi pemodelan dapat memampukan siswa kelas XII SMA Negeri Tahuna menulis teks editorial.

\section{KESIMPULAN}

Berdasarkan hasil dan pembahasan penelitian maka dapat disimpulkan sebagai berikut.

1) Penggunaan strategi pemodelan dalam menulis teks editorial terdiri dari empat tahapan inti ternyata memberikan kesempatan yang begitu besar kepada siswa terlibat secara aktif dalam pembelajaran menulis. Hasil penelitian menunjukkan juga bahwa penggunaan strategi pemodelan yang digunakan dalam pembelajaran menulis teks editorial pada siswa kelas XIIA SMA Negeri 1 Tahuna memfokuskan kegiatan siswa pada menelaah dan menulis teks editorial, di mana siswa diberi dua teks model yang mereka dapat jadikan sebagai acuan sehingga mereka dapat menulis dengan baik. Pengalaman yang relevan dimiliki berkaitan dengan materi pembelajaran sangat membantu mereka menguasai materi yang dipelajari. Dengan menelaah terlebih dahulu teks editorial yang dijadikan model sebagai acuan siswa menulis memberikan pengetahuan dan pengalaman penting kepada siswa menulis teks editorial.

2) Kemampuan siswa menulis teks editorial dengan strategi pemodelan adalah $\mathbf{8 1 . 7 1}$ atau berada pada kategori mampu. Nilai rata-rata siswa secara klasikal yang dicapai siswa melampaui Kriteria Ketuntasan Minimal (KKM) yang ditentukan guru bahasa Indonesia di kelas XII SMA Negeri 1 Tahuna, yakni 78, maka nilai rata-rata yang dicapai oleh siswa ini secara klasikal melampaui ketuntasan minimal. 


\section{DAFTAR PUSTAKA}

Arends, R.I. 2008. Learning to Teach. Belajar untuk Mengajar. Terjemahan Helly Prajitno Soejipto dan Sri Mulyanti Soejipto. Yogyakarta: Pustaka Pelajar.

Ali, Mohamad. 1985. penelitian pendidikan prosedur dan model. Bandung : Angkasa.

Depdiknas. 2004. Pelajaran Bahasa Indonesia. Jakarta: Diretktorat Jenderal Peningkatan Mutu Sekolah Menengah.

Devita Sari, G. 2015. Keefektivan Strategi Pemodelan dalam Pembelajaran Menulis. Teks Cerita Pendek Siswa Kelas X SMA. Artikel Penelitian. journal. Student.uny.ac.id.

Kemendikbud, 2013. Kurukulum 2013. Jakarta: Pusat Kurikulum.

Mahsun. 2014. Teks dalam Pembelajaran Bahasa Indonesia, Kurikulum 2013. Jakarta: PT Raja Grafindo Persada.

Suherli, dkk Suherli,dkk.2018. Buku Siswa bahasa Indonesia kelas XII Revisi Tahun 2018. Jakarta: Kemedikbud.

Sukmadinata. (2009). Metode Penelitian Pendidikan. Bandung: Rosdakarya.

Setiarini I.W. \& Artini MG. 2018. Bahasa Indonesia SMA.MA Kelas XII. Jakarta: Yudhistira.

Sugondo, dkk. 2005. Kamus Pelajar. Jakarta: Pusat Bahasa Departemen Pendidikan Nasional. 